\title{
Glutathione levels in and total antioxidant capacity of Candida sp. cells exposed to oxidative stress caused by hydrogen peroxide
}

\author{
Maxwel Adriano Abegg ${ }^{[1],[2]}$, Paulo Vinícius Gil Alabarse ${ }^{[1]}$, Ártur Krumberg Schüller ${ }^{[3]}$ and Mara Silveira Benfato ${ }^{[1],[3]}$
}

[1]. Programa de Pós-Graduação em Biologia Celular e Molecular, Universidade Federal do Rio Grande do Sul, Porto Alegre, RS. [2]. Instituto de Ciências Exatas e Tecnologia, Universidade Federal do Amazonas, Itacoatiara, AM. [3]. Departamento de Biofísica, Universidade Federal do Rio Grande do Sul, Porto Alegre, RS.

\begin{abstract}
Introduction: The capacity to overcome the oxidative stress imposed by phagocytes seems to be critical for Candida species to cause invasive candidiasis. Methods: To better characterize the oxidative stress response (OSR) of 8 clinically relevant Candida sp., glutathione, a vital component of the intracellular redox balance, was measured using the 5,5'-dithiobis-(2-nitrobenzoic acid (DTNB)-glutathione disulfide (GSSG) reductase reconversion method; the total antioxidant capacity (TAC) was measured using a modified method based on the decolorization of the 2,2'-azinobis-(3-ethylbenzothiazoline-6-sulfonic) acid radical cation (ABTS*+). Both methods were used with cellular Candida sp. extracts treated or not with hydrogen peroxide $(0.5 \mathrm{mM})$. Results: Oxidative stress induced by hydrogen peroxide clearly reduced intracellular glutathione levels. This depletion was stronger in Candida albicans and the levels of glutathione in untreated cells were also higher in this species. The TAC demonstrated intra-specific variation. Conclusions: Glutathione levels did not correlate with the measured TAC values, despite this being the most important non-enzymatic intracellular antioxidant molecule. The results indicate that the isolated measurement of TAC does not give a clear picture of the ability of a given Candida sp. to respond to oxidative stress.
\end{abstract}

Keywords: Candida sp. Glutathione. Total antioxidant capacity.

\section{INTRODUCTION}

Candida albicans, C. glabrata, C. tropicalis, and C. parapsilosis account for approximately $95 \%$ of identifiable Candida infections. Other species, including C. krusei, C. Iusitaniae, and C. guilliermondii, account for less than $5 \%$ of cases of invasive candidiasis. The most common causative agent is still $C$. albicans, but its incidence is declining and the frequencies of other species are increasing. Recently, Furlaneto et al. ${ }^{1}$ noted that non-albicans Candida was the predominant species in different clinical specimens, with the exception of urine samples, in a Brazilian tertiary-care hospital. Invasive candidiasis has a mortality rate that approaches $40 \% \%^{2,3}$. Although most people are colonized by Candida sp., the majority never develop invasive candidiasis. Alterations in host immunity, physiological features, or normal microflora, rather than the acquisition of novel or hypervirulent factors by Candida, are suggested to degenerate the commensal-host interaction and lead to an opportunistic infection ${ }^{4}$.

During the course of a systemic infection, Candida cells are engulfed by host phagocytes, where they are exposed to reactive oxygen species (ROS) $)^{5}$. ROS contribute to the killing of $C$. albicans in both cultured cells and entire organisms ${ }^{6-9}$. Upon incubation with macrophages, C. albicans deoxyribonucleic acid (DNA) repair genes are transcriptionally induced, suggesting that DNA damage indeed occurs in the phagosome and that genotoxic hypersensitivity stress would be disadvantageous to the pathogen ${ }^{10}$. Recently, it was demonstrated that a large proportion of $C$. albicans cell surface antigens related to acute candidemia are involved in oxidative stress ${ }^{4}$. In C. albicans, hyphal cells

Address to: Mara S. Benfato. Depto de Biofísica/UFRGS. Av. Bento Gonçalves 9500/ Prédio 43431, 91501-970 Porto Alegre, RS, Brasil.

Phone: 5551 3308-7603; Fax: 5551 3308-7003.

e-mail: mara.benfato@ufrgs.br

Received in 08/05/2011

Accepted in 06/02/2012 are more resistant to oxidative stress ${ }^{10}$, and hyphal formation is higher in isolates resistant to azole drugs ${ }^{11}$. Taking into account these data, overcoming the oxidative phagocytic challenge seems to be critical for the establishment of candidemia.

Candida species have evolved an antioxidant defensive response in order to withstand ROS attack, which encompasses, among other components, glutathione (GSH, L- - -glutamyl-L-cysteinyl-glycine) and GSH-related activities (i.e., glutathione reductase, glutathione peroxidase, and glucose-6P-dehydrogenase $)^{12}$. GSH is the most abundant non-protein thiol in eukaryotic cells and its very low redox potential $\left(E_{0}^{\prime}=-240 \mathrm{mV}\right)$ provides the cell with redox buffer properties. In budding yeasts, GSH and its oxidized disulfide form (GSSG) are involved in essential physiological functions, such as DNA and protein synthesis, transport, and cellular detoxification ${ }^{13}$. Yeast isolates lacking glutathione or that have altered glutathione redox states are sensitive to peroxide-induced oxidative stress, superoxide anions, and lipid peroxidation products ${ }^{13-16}$.

Numerous assays have been described to measure antioxidant status, but it seems that no ideal method is available ${ }^{17}$. Different antioxidants can be measured separately, but the measurements are time-consuming, labor-intensive, costly, and often require complicated techniques ${ }^{18,19}$. Hence, the concept of a single test that might reflect the total antioxidant capacity (TAC) of biological fluids has elicited interest. The most widely used colorimetric methods to measure TAC are 2,2'-azinobis-(3-ethylbenzothiazoline-6-sulfonic) acid radical cation (ABTS*+)-based methods. Reduced ABTS, a colorless molecule, is oxidized to ABTS*+, which is characteristically blue-green. When this radical is mixed with any oxidizable substance, it is reduced to its colorless form ${ }^{18}$.

Different Candida sp. exhibit unequal oxidative stress resistances in vitro $^{20-22}$, and different in vitro virulence potential $\mathrm{s}^{23}$, and we proposed that this may contribute to the capacity of each species to cause candidemia ${ }^{22}$. Taking into account these differences, total glutathione levels and the cellular TAC were assessed in 8 Candida species. 


\section{METHODS}

\section{Yeast isolates and cultivation}

The following yeast isolates were used: $C$. albicans type strain ATCC 18804, C. dubliniensis type strain from the Centraalbureau voor Schimmelcultures (CBS) 7987, C. famata ATCC 62894, C. glabrata type strain ATCC 2001, C. guilliermondii type strain ATCC 46036, C. guilliermondii ATCC 6260, C. krusei type strain ATCC 6258, C. parapsilosis type strain ATCC 22019, and C. tropicalis ATCC 13803. The clinical isolates used were as follows: $C$. albicans 1 (isolate from a patient with nosocomial infection); $C$. albicans 51 (isolate from the orotracheal tube of an acquired immunodeficiency syndrome (AIDS) patient); $C$. dubliniensis 23 and $C$. dubliniensis 25 (both from the oropharynx of AIDS patients); C. famata 1 and C. famata 24 (both clinical isolates from patients with nosocomial infection); C. glabrata 1, C. glabrata 75, and C. glabrata 118 (all obtained from catheter tips); C. guilliermondii 73 (clinical isolate from a patient with nosocomial infection); C. krusei 1 and C. krusei 2 (both isolated from skin lesions of diabetic patients); C. parapsilosis 81 and C. parapsilosis 115 (both isolated from patients with onychomycosis); C. tropicalis 1 (isolated from an oral granuloma); and C. tropicalis 55 and C. tropicalis 56 (both clinical isolates from a patient with nosocomial infection).

The isolates were identified and maintained as previously described $^{22}$. Viable cells were obtained by cultivation on solid yeast extract-peptone-dextrose (YPD) medium (1\% yeast extract, $2 \%$ peptone, $2 \%$ glucose, $2 \%$ agar), and isolates were then grown in liquid YPD medium in an orbital shaker at $30^{\circ} \mathrm{C} / 100 \mathrm{rpm}$ to late exponential growth $\left(O D_{600 \mathrm{~nm}}=1.5-1.6\right)$. Cells were washed twice with sterile distilled water and diluted to $\mathrm{OD}_{600 \mathrm{~nm}}=0.15$ in fresh liquid YPD for use. Cells were grown at $30^{\circ} \mathrm{C}$ rather than at $37^{\circ} \mathrm{C}$ because $\mathrm{C}$. dubliniensis and $\mathrm{C}$. famata grow better at $30^{\circ} \mathrm{C}$.

\section{Cell-free extracts}

Cell suspensions $(1.5 \mathrm{~mL})$ were centrifuged for $5 \mathrm{~min}$ at $8,000 \mathrm{~g}$ and lysed by adding $0.5 \mathrm{~mL}$ of lysis buffer $(50 \mathrm{mM}$ Tris-Cl, $150 \mathrm{mM}$ $\mathrm{NaCl}, 50 \mathrm{mM}$ ethylenediamine tetraacetic acid [EDTA], pH 7.2), 50mM phenyl methyl sulfonyl fluoride (PMSF; Sigma, St. Louis, MO) and approximately $0.5 \mathrm{~g}$ of glass beads (diameter, $425-600 \mu \mathrm{m}$; Sigma). Lysis was performed by vortexing for 3 mixing cycles of $3 \mathrm{~min}$ with 1-min intervals for cooling on ice. Breakage was checked microscopically. The samples were then centrifuged for $10 \mathrm{~min}$ at $8,000 \mathrm{~g}$ to remove cellular debris and beads.

\section{Total glutathione assay}

Total intracellular glutathione was determined by the 5,5'-dithiobis(2-nitrobenzoic acid (DTNB)-glutathione disulfide GSSG reductase recycling method ${ }^{24,25}$. Cell suspensions were left untreated or were treated with $0.5 \mathrm{mM} \mathrm{H}_{2} \mathrm{O}_{2}$, incubated for $1 \mathrm{~h}$ with agitation at $100 \mathrm{rpm} / 30^{\circ} \mathrm{C}$, washed with sterile distilled water, and then resuspended to the same volume in $100 \mathrm{mM}$ potassium phosphate buffer ( $\mathrm{pH} 7.0)$, lysed, and centrifuged. Then, $25 \mu \mathrm{L}$ aliquots of the supernatants were vortexed thoroughly with an equal volume of $2 \mathrm{M} \mathrm{HClO}_{4}$ and $4 \mathrm{mM}$ EDTA. After $15 \mathrm{~min}$ incubation at $0^{\circ} \mathrm{C}$, the suspensions were centrifuged for $5 \mathrm{~min}$ at $8,000 \mathrm{~g}$ and $45 \mu \mathrm{L}$ of the supernatant was $\mathrm{pH}$-neutralized by adding $3 \mu \mathrm{L}$ of $2 \mathrm{M} \mathrm{KOH}$ at $0^{\circ} \mathrm{C}$. This was centrifuged for $1 \mathrm{~min}$ at $8,000 \mathrm{~g}$ and $35 \mu \mathrm{L}$ of the supernatant was added to a mixture containing $174 \mu \mathrm{L}$ of $100 \mathrm{mM}$ phosphate buffer $(\mathrm{pH} 7.0), 17 \mu \mathrm{L}$ of $4 \mathrm{mM} \mathrm{NADPH}$, and $7 \mu \mathrm{L}$ of glutathione reductase solution $(6 \mathrm{U} / \mathrm{mL})$. This was mixed and incubated for 5 min at $37^{\circ} \mathrm{C}$. Then, $18 \mu \mathrm{L}$ of DTNB reagent $(0.040 \mathrm{~g}$ of DTNB [Sigma] dissolved in $10 \mathrm{ml}$ of $50 \mathrm{mM}$ potassium phosphate buffer, $\mathrm{pH} 7.0$ ) was added, and the absorbance was read at $412 \mathrm{~nm}$ after a $2-\mathrm{min}$ incubation at $37^{\circ} \mathrm{C}$.

\section{Total antioxidant capacity}

A modified method based on ABTS*+ decolorization described by Erel ${ }^{18}$ was employed. Cell suspensions were treated with $0.5 \mathrm{mM}$ $\mathrm{H}_{2} \mathrm{O}_{2}$, washed, lysed, and centrifuged, as previously described ${ }^{22}$, and $5 \mu \mathrm{L}$ of each supernatant was mixed with $200 \mu \mathrm{L}$ of $0.4 \mathrm{~mol} / \mathrm{L}$ acetate buffer, $\mathrm{pH}$ 5.8. Then, $20 \mu \mathrm{L}$ of ABTS*+ in $30 \mathrm{mM}$ acetate buffer, $\mathrm{pH}$ 3.6, was added, mixed, and the absorbance measured after 5 min. The absorbance of a solution without ABTS $^{*+}$ was also measured as the blank. The vitamin E water-soluble analogue 6-hydroxy2,5,7,8-tetramethylchroman-2-carboxylic acid (Trolox) was used as the standard, and data were expressed in terms of mmol Trolox equivalent per milligram of protein.

\section{Total protein content}

The total protein content in lysed cells was determined by the Bradford assay (Bio-Rad, Hercules, CA).

\section{Statistics}

Statistical analyses were performed using the PASW software, v. 18.0 (SPSS, Chicago, IL). One-way ANOVA was performed, followed by the Tukey post hoc test to compare differences among groups. The Student's $t$-test was used to compare treated and untreated samples. Correlations were determined based on Spearman rank correlation coefficient (rho). Some statistical data have been omitted from the figures to facilitate visualization.

\section{RESULTS}

In the present work, the levels of total intracellular GSH following mild oxidative stress in Candida sp. were determined. GSH levels ranged from 80 to $290 \mathrm{nmol} / \mathrm{mg}$ of protein in untreated samples and from 21 to $83 \mathrm{nmol} / \mathrm{mg}$ of protein in treated samples (Figure 1). With exception of C. tropicalis, all species tested exhibited a significant reduction in total GSH levels following exposure to mild oxidative stress $\left(0.5 \mathrm{mM} \mathrm{H}_{2} \mathrm{O}_{2}\right)$. C. albicans presented the most dramatic reduction. In untreated samples, C. albicans presented the highest GSH levels and these levels were significantly higher than those seen in C. dubliniensis, C. guilliermondii, C. krusei, C. parapsilosis, and C. tropicalis ( $<0.05)$ (Figure 1).

The TAC results were quite varied in each species (Figure 2). One $C$. albicans isolate (51), 2 C. guilliermondii isolates (6260 and 73), and $1 C$. krusei isolate (6258) presented the highest TAC levels. With exception to $C$. guilliermondii isolate 73 in comparison with $C$. tropicalis isolate 55 , the isolates cited above exhibited significant differences in TAC levels compared to all other isolates tested $(p<0.05)$.

Concerning Spearman rank correlation coefficient, TAC results did not correlate ( $r$ ho $=0.051$ ) with sensitivity of Candida $\mathrm{sp}$. isolates to oxidative stress. TAC results also did not correlate with total intracellular GSH levels in untreated ( $r h o=0.042$ ) and treated (rho $=0.058$ ) samples. 


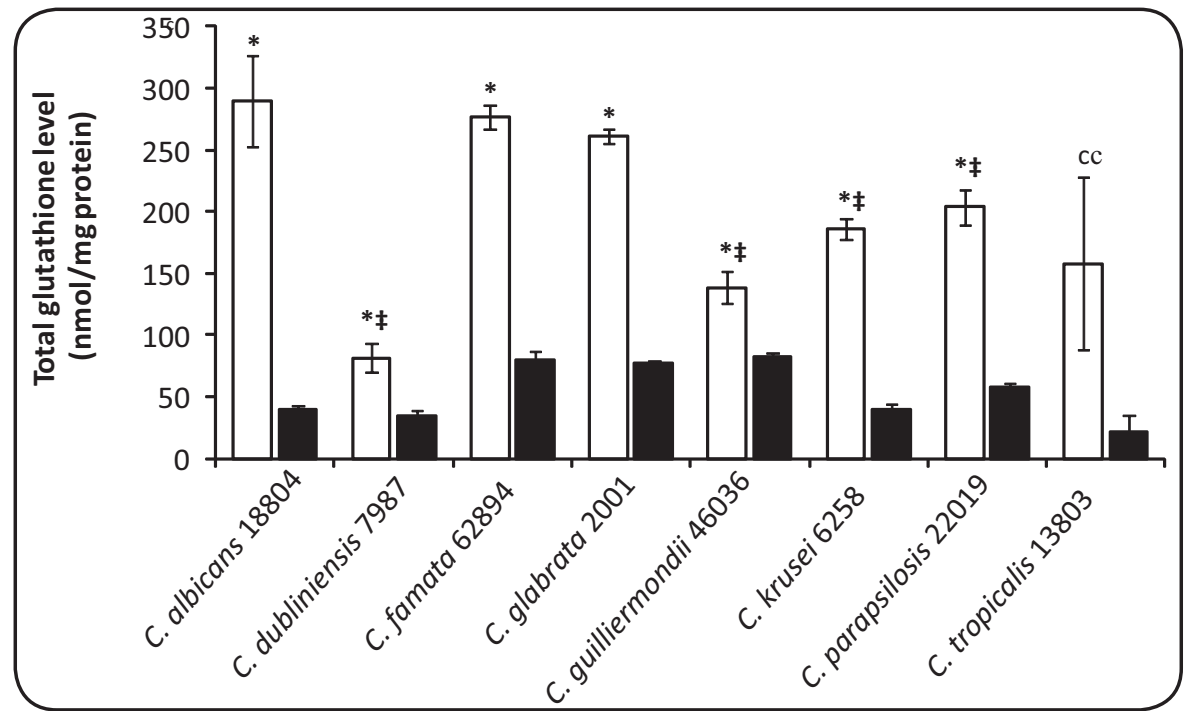

FIGURE 1 - Effect of $0.5 \mathrm{mM} \mathrm{H}_{2} \mathrm{O}_{2}$ on the total intracellular glutathione concentration ( $\mathrm{nmol}$ (GSH + 2GSSG) mg ${ }^{-1}$ protein) in Candida sp. Cells were treated (black bars) or not (white bars), as described in Methods. Asterisks (*) indicate significant differences $(p<0.01)$ between untreated and treated samples. The symbol $(\ddagger)$ indicates significant differences between untreated Candida albicans cells and the isolates labeled. The data are the mean \pm SD values of 3 independent experiments. C: Candida.

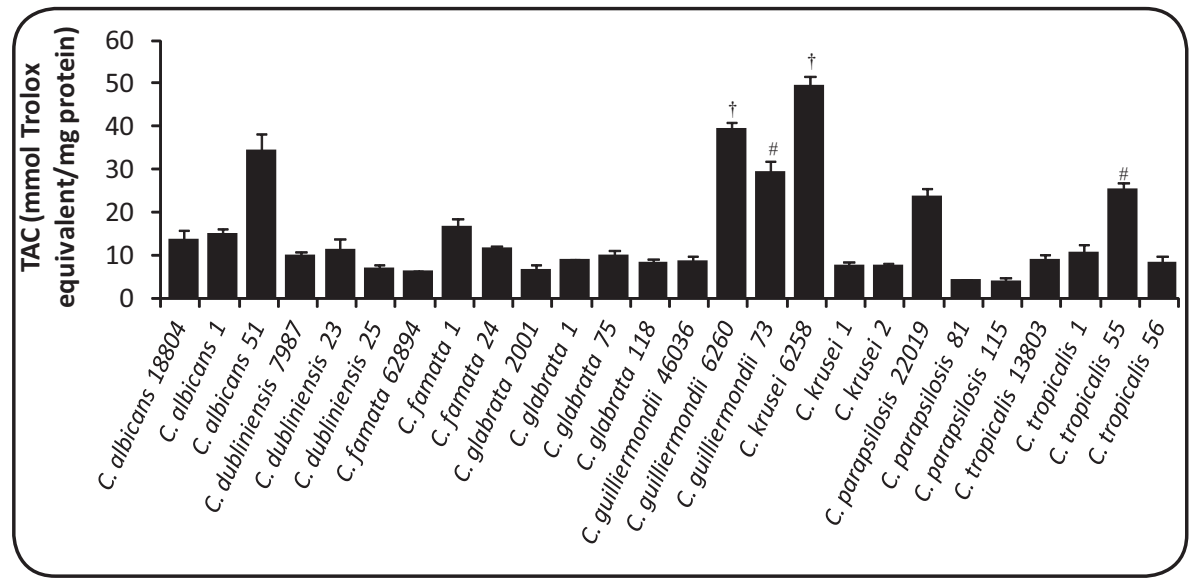

FIGURE 2 - Total antioxidant capacity in Candida sp. cells after $0.5 \mathrm{mM} \mathrm{H}_{2} \mathrm{O}_{2}$ treatment. Cells were treated as described in Materials and Methods. Each column corresponds to the Candida isolate identified below. The symbol ( + ) indicates significant differences $(p<0.05)$ between the labeled isolate and all the other isolates tested. The symbol (\#) indicates that the isolate Candida guilliermondii was not significantly different from the isolate Candida tropicalis 55 ( $p>0.05$ ), but was significantly different from all other isolates tested. The data represent the mean $\pm S D$ values of 3 independent experiments. $\boldsymbol{C}$ : Candida; TAC: total antioxidant capacity.

\section{DISCUSSION}

The virulence of Candida albicans seems to be multifactorial ${ }^{26}$, but the ability of this fungus to mount stress responses is an important aspect, as this promotes survival in the host during systemic infections ${ }^{27}$. In a previous study by our group ${ }^{22}$, we analyzed the oxidative effects (degree of resistance and induction of oxidative damage) and antioxidative effects (capacity to adapt and induction of antioxidative enzymes). Here, we continued the characterization of the oxidative stress response (OSR) of 8 clinically relevant Candida sp.

Hydrogen peroxide was used to generate oxidative stress. $\mathrm{H}_{2} \mathrm{O}_{2}$ itself is not very reactive, but can be further reduced to extremely damaging hydroxyl radicals. Therefore, all aerobic cells are equipped with $\mathrm{H}_{2} \mathrm{O}_{2}$-removing enzymes. Furthermore, evidence suggests that $\mathrm{H}_{2} \mathrm{O}_{2}$ is produced transiently in response to the activation of many cell surface receptors and serves as an intracellular messenger. The timely elimination of intracellular messengers after the completion of their mission is critical for receptor signaling. This would seem especially true for $\mathrm{H}_{2} \mathrm{O}_{2}{ }^{28}$. According to $\mathrm{Ng}$ et al. ${ }^{29}$ the network of enzymes that detoxify $\mathrm{H}_{2} \mathrm{O}_{2}$ in biological systems has at least 3 nodes: catalase (which is the longest known enzyme for the removal of $\mathrm{H}_{2} \mathrm{O}_{2}$ and requires no cofactors), 6 members of the peroxiredoxin family of enzymes, and the glutathione peroxidases that rely on GSH as the electron donor and specific cofactor.

The GSH levels (90-152) observed by Fekete et al. ${ }^{30}$ in untreated C. albicans isolates were similar to the levels found in this study (Figure 1). 
Consistent with this, Lemar et al. ${ }^{31}$ showed that a $30-$ min C. albicans exposure to $0.5 \mathrm{mM}$ diallyl disulfide (a garlic oxidative constituent) decreased intracellular GSH and elevated ROS intracellular levels. It was also demonstrated that $\mathrm{H}_{2} \mathrm{O}_{2}$ exposure causes a reduction in intracellular GSH levels, particularly for Saccharomyces cerevisiae, as well as a shift in the GSH redox balance towards the oxidized form, GSSG, as reviewed in Penninckx ${ }^{13}$. Thomas et al. ${ }^{32}$ reported a dramatic decline in the level of intracellular GSH, concomitant with the yeast-to-mycelial conversion, in C. albicans. Consistent with this, Michán and Pueyo ${ }^{33}$ reported that the GSH levels in C. albicans hyphae were approximately $50 \%$ of those in yeasts. Considering that oxidative stress diminishes $\mathrm{GSH}$ level ${ }^{33,34}$, our treatment with $\mathrm{H}_{2} \mathrm{O}_{2}$ was expected to reduce GSH content. Pacheco et al..$^{25}$ demonstrated that cadmium treatment increased ROS production, depleted intracellular GSH concentrations, and increased external GSH concentrations. Furthermore, González-Párraga et al. ${ }^{12}$ used the oxidant 1-chloro-2,4dinitrobenzene to reduce intracellular GSH levels in Candida. Madeo et al..$^{35}$ also demonstrated that treatment with $3 \mathrm{mM} \mathrm{H}_{2} \mathrm{O}_{2}$ induced intracellular GSH depletion and apoptosis in S. cerevisiae.

In contrast, Fekete et al. ${ }^{36}$ found GSH levels of $\sim 160 \mathrm{nmol} / \mathrm{mg}$ of protein in untreated isolates of $C$. albicans and $\sim 260 \mathrm{nmol} / \mathrm{mg}$ of protein after treatment with $1 \mathrm{mM}$ tert-butil-hydroperoxide, an oxidant. Lee et al. ${ }^{37}$ found that a 6 -h treatment with $0.1 \mathrm{mM} \mathrm{H}_{2} \mathrm{O}_{2}$ provoked a 3.14-fold elevation in GSH levels in Schizosaccharomyces pombe. Manfredini et al. ${ }^{38}$ reported an increase in GSH levels upon treatment with $0.5 \mathrm{mM} \mathrm{H}_{2} \mathrm{O}_{2}$ in wild-type $S$. cerevisiae cells and a significant reduction in those levels with $5 \mathrm{mM} \mathrm{H}_{2} \mathrm{O}_{2}$. These differences regarding our results may be related to the duration of treatment, the use of different oxidants or lower doses of hydrogen peroxide, or to differences in the metabolic activities of the species. In the case of $S$. cerevisiae, it could be related to the higher sensitivity of this species to $0.5 \mathrm{mM} \mathrm{H}_{2} \mathrm{O}_{2}$ in comparison to that of Candida sp. This concentration may induce $40 \%$ lethality in $S$. cerevisiae and is normally sublethal (95-100\% viability) in the case of Candida sp. ${ }^{22,39}$.

GSH can occur in yeasts in the reduced form (GSH), the oxidized form (GSSG), and as different mixed disulfides, for example GS-S-COA and GS-S-Cys ${ }^{13}$. The $\mathrm{H}_{2} \mathrm{O}_{2}(0.5 \mathrm{mM} / 1 \mathrm{~h}$ treatment) used to induce oxidative stress was probably detoxified in part through the action of the enzyme glutathione-peroxidase (GPX) and the concomitant conversion of GSH into GSSG ${ }^{29}$. Increasing GSSG levels can potentially inhibit protein synthesis in animal and plant cell ${ }^{40,41}$, and because of this, Candida cells are likely to export GSSG under conditions of oxidative stress, resulting in a decrease in total intracellular glutathione levels.

In yeasts, peroxide resistance has been associated with intracellular GSH levels ${ }^{42-44}$. Further, it has been previously proposed that the rate of removal of $\mathrm{H}_{2} \mathrm{O}_{2}$ is a direct function of GPx activity $\times$ $\mathrm{GSH}^{29}$. The highest levels of GSH observed and the intense diminution of intracellular GSH levels in C. albicans (Figure 1), together with the GPx activities previously observed for this species ${ }^{20}$ (Abegg et al. unpublished results), may indicate a more efficient detoxification system of $\mathrm{H}_{2} \mathrm{O}_{2}$ through $\mathrm{GPx} / \mathrm{GSH}$ in C. albicans than in other Candida sp. However, the limitations of the GSH results should be noted, particularly because of the use of 1 isolate of each species, and further comparisons regarding GSH metabolism should be made.

Total antioxidant capacity assays may be broadly classified as electron transfer (ET)-based and hydrogen atom transfer (HAT)-based assays, although these 2 mechanisms may not be differentiated with distinct boundaries in some cases. In fact, most non-enzymatic antioxidant activity (e.g., scavenging of free radicals and inhibition of lipid peroxidation) is mediated by redox reactions. Electron transfer assays include the ABTS, Trolox equivalent antioxidant capacity (TEAC), cupric-reducing antioxidant capacity (CUPRAC), di(phenyl)(2,4,6-trinitrophenyl)iminoazanium (DPPH), Folin-Ciocalteu, and ferric-reducing antioxidant power (FRAP) methods, each of which use different chromogenic redox reagents with different standard potentials (reviewed in Apak et al. ${ }^{45}$ ).

The ET mechanism of antioxidant action is based on the following reactions: (1) ROO. $+\mathrm{AH} / \mathrm{ArOH} \rightarrow \mathrm{ROO}^{-}+\mathrm{AH}^{+} / \mathrm{ArOH}{ }^{+}{ }^{+}$, (2) $\mathrm{AH} .{ }^{+} / \mathrm{ArOH} .^{+}$ $+\mathrm{H}_{2} \mathrm{O} \leftrightarrow$ A./ArO. $+\mathrm{H}_{3} \mathrm{O}^{+}$, and (3) ROO- $+\mathrm{H}_{3} \mathrm{O}^{+} \leftrightarrow \mathrm{ROOH}+\mathrm{H}_{2} \mathrm{O}$; these reactions are relatively slower than those of HAT-based assays and are solvent-and pH-dependent ${ }^{45}$. Re et al ${ }^{46}$ and Erel ${ }^{18}$ developed improved ABTS radical cation decolorization assays using persulfate and hydrogen peroxide, respectively, as the oxidant, and thereby compensated for the weaknesses of the original ferryl myoglobulin/ABTS assay. The 3 TEAC tests developed at different periods, namely the TEAC assay I (ABTS*+ generated enzymatically with metmyoglobin and hydrogen peroxide), TEAC II (radical generation with filtration over the $\mathrm{MnO}_{2}$ oxidant), and TEAC III (with $\mathrm{K}_{2} \mathrm{~S}_{2} \mathrm{O}_{8}$ oxidant), are entirely different from each other, are applicable to different solvent media, and their findings for a given antioxidant can vary significantly. The 'pre-addition technique' as in TEAC I, involving the addition of antioxidants before radical generation, could result in an overestimation of antioxidant capacity, because many substances interfere with the formation of the radical; therefore, TEAC I measures the ability to delay radical formation as well as the scavenging of the radical ${ }^{45}$.

The advantages of ABTS/TEAC are reported to be operational simplicity, reproducibility, diversity, and most importantly, flexible usage in multiple media to determine both the hydrophilic and lipophilic antioxidant capacities of physiological fluids, since the reagent is soluble in both aqueous and organic solvent media. Aqueous- and lipid-soluble antioxidants are not separated in the TAC protocol employed; therefore, the combined antioxidant activities of all its constituents, including vitamins, proteins, lipids, glutathione, and uric acid, are assessed ${ }^{45}$.

The intra-specific TAC variation found here is in agreement with observed variations in the sensitivities of $C$. albicans isolates to oxidants ${ }^{47}$. However, the TAC results did not correlate $(r h o=0.051)$ with the previously reported sensitivity of Candida $\mathrm{sp}$. isolates to oxidative stress ${ }^{22}$. One C. albicans isolate (51), 2 C. guilliermondii isolates (6260 and 73), and $1 C$. krusei isolate (6258) showed the highest TAC levels. With the exception of the comparison of $C$. guilliermondii isolate 73 with $C$. tropicalis isolate 55 , the isolates cited above exhibited significant differences in TAC levels in comparison to all the other isolates tested $(p<0.05)$.

Lapshina et al..$^{48}$ compared differences in the ability to scavenge nitroxide (4-amino-2,2,6,6-tetramethylpiperidinoxy; TEMPO), stable free radicals, and alkoxyl free radicals generated by the decomposition of the free radical initiator 2,2'-azobis-2-methyl-propanimidamide dihydrochloride (AAPH) in S. cerevisiae strains defective in catalase and superoxide dismutase and with a decreased level of glutathione. Unlike the results obtained here for Candida isolates (Figure 2), S. cerevisiae cell homogenates did not show considerable strain-related differences. 
The TAC based on the scavenging of ABTS free radicals showed a good correlation with the radiation resistance of the yeasts. According to the authors, the results point to the importance of factors other than antioxidative enzymes and glutathione, in the determination of cellular resistance to ionizing radiation and other types of free-radical stress in S. cerevisiae.

Balcerczyk et al. ${ }^{49}$ demonstrated that the TAC of cell extracts of $S$. cerevisiae showed a stronger dependence on the thiol content as evidenced by the effect of -SH blocking with n-ethylmaleimide (NEM). TAC measured after $10 \mathrm{~s}$ was decreased by $83-90 \%$ (in different strains) following thiol modification, while TAC measured after a 1-min reduction of $\mathrm{ABTS}^{*+}$ was decreased by $73-80 \%$. According to the authors, the results indicate that thiol groups are a major contributor to the TAC of S. cerevisiae and perhaps of other yeast species. These results demonstrate that in cell extracts, in contrast to extracellular fluids, thiol groups constitute the dominant determinant of total antioxidant capacity, at least in S. cerevisiae. Depletion of thiols leads to a decrease in TAC. However, cellular adaptation to oxidative stress may involve the mobilization of mechanisms other than an increase in thiol concentrations. This is especially evident in yeast cells, where strains deficient in antioxidant enzymes show increased values of TAC due mainly to thiol-independent mechanisms. Similarly, the adaptation of yeast to conditions of stationary culture and reoxygenation after growth under anoxia predominantly involves antioxidants other than thiols, as demonstrated by Balcerczyk et al. ${ }^{49}$.

Considering the mode of action of the enzymes of the peroxiredoxin (Prx) family, which consists of thiol-dependent peroxidases involved in the removal of various types of hydroperoxides in cells, such as hydrogen peroxide, organic peroxides, and peroxynitrite ${ }^{50,51}$, and based on the results described above, these enzymes seem to be critical in determining the TAC of yeast cells. In addition to detoxifying peroxides, specific peroxiredoxins have been shown to act as molecular chaperones and to play roles in regulating hydrogen peroxide-mediated cell signaling events ${ }^{51}$. In S. cerevisiae, for example, the steady-state protein level of the peroxiredoxin Tsa1 is 45 times that of $\mathrm{Gpx} 3^{52,53}$. Tsa1 is also the key peroxidase suppressing genome instability and protecting against cell death in S. cerevisiae ${ }^{54,55}$. Furthermore, in S. cerevisiae, Demasi et al. ${ }^{56}$ demonstrated the importance of cytosolic thioredoxin peroxidase I (cTPxI) and its reductant sulfiredoxin in the protection of cells suffering mitochondrial dysfunction, against $\mathrm{H}_{2} \mathrm{O}_{2}$ induced death.

In S. cerevisiae, there are 5 isoforms of Prx, distributed in different cellular compartments ${ }^{57}$. The 2 most abundant peroxiredoxins in these species are Ahp1 and Tsa1 ${ }^{58}$. The TSA1 gene is present in C. albicans, C. glabrata, $C$. tropicalis, and $C$. dubliniensis and is similar to the TSA1 and TSA2 of S. cerevisiae. AHP 11, AHP 12, and AHP 13 are genes from strain SC5314 of $C$. albicans and show similarity to the $S$. cerevisiae alkyl hydroperoxide reductase AHP1 (YLR109W) ${ }^{59}$.

Urban et al. ${ }^{60}$ reported the identification of Tsa1p, a protein that is differentially localized to the cell wall of $C$. albicans in hyphal cells but remains in the cytosol and nucleus in yeast-form cells. According to the authors, this is different from S. cerevisiae, where the homologous protein solely has been found in the cytoplasm. These authors reported that TSA1 confers resistance towards oxidative stress in addition to being involved in the correct composition of hyphal cell walls. Shin et al. ${ }^{61}$ also observed that the protein Tsa1p codified by this gene was indispensable in the yeast-to-hyphal transition when C. albicans was cultured under oxidative stress. In C. albicans, the genes AHP1 and HSP12 are regulated by the response regulator gene SSK1, and those genes are associated with cell wall biosynthesis and adaptation to oxidative stress ${ }^{62}$. Therefore, it seems that the peroxiredoxin system is critical for the functioning of the antioxidant system of Candida and is one of the most important contributors to the TAC in Candida cell lysates.

As far as we are aware, this is the first attempt to use a single test of TAC in Candida. The use of a single marker of antioxidant capacity has drawbacks and these data must be interpreted with caution. According to Young ${ }^{17}$, these single markers measure predominantly low molecular weight and chain-breaking antioxidants, excluding the contributions of antioxidant enzymes and metal binding proteins. The fact that the TAC results did not correlate with the sensitivity of Candida sp. isolates to oxidative stress has been reported previously ${ }^{22}$ (Abegg et al. unpublished results); the fact that it also did not correlate with total intracellular GSH levels in untreated ( $r$ o $=0.042$ ) and treated (rho $=0.058)$ samples may indicate that a single marker cannot provide a picture of the antioxidant capacity of a Candida sp.

Fekete et al. ${ }^{30}$ searched for $C$. albicans isolates that are naturally resistant to oxidative stress but did not find this phenotype. They argued that the selection of mutants that are tolerant to oxidative stress in vivo would be beneficial to the pathogen-phagocyte interaction, but would be unlikely because of the concomitant and disadvantageous changes in virulence attributes, like morphological transitions and phospholipase secretion. They also point out that an over-efficient antioxidative defense system may be disadvantageous for $C$. albicans by hindering the ROS-triggered activation of genomic ageing and cell death programs that promote adaptation to stresses in the human body. Besides the unlikely selection of $C$. albicans mutants that are naturally oxidant-resistant, certain species like $C$. dubliniensis, $C$. guilliermondii, and $C$. famata are probably not evolutionarily prepared to cope with the first line of immune defense and oxidative stress, even in moderately immunocompromised individuals. This would be reflected in the relative incidence of this species as a causal agent of invasive candidiasis.

Macrophages and neutrophils use ROS, reactive nitrogen species (RNS), and chlorine species for host protection ${ }^{6-9,63}$, but the idea that ROS exert direct in vivo effects in the fungal killing of Candida and other species is still controversial. Balish et al. ${ }^{64}$ studied the deficient production of ROS and RNS in mice using gastrointestinal Candida inoculation. Although these mice died, an exaggerated immune response rather than an overwhelming fungal infection appeared to cause death. Further, an in vitro study with phagocytes from normal and ROS/RNS-deficient mice revealed equal abilities of both to kill $C$. albicans. Wellington et al. ${ }^{65}$ considered these data to be in agreement with their results of $C$. albicans suppression of ROS production in phagocytes. However, it seems to be clear that Candida species have distinct capacities to deal with oxidative stress, and the inhibition of specific antioxidant molecules may be therapeutically useful in the future.

\section{ACKNOWLEDGMENTS}

The authors thank Marilene Henning Vainstein, Terezinha Inez Estivalet Svidzinski, Sydney Hartz Alves, and the Instituto Nacional de Controle de Qualidade em Saúde (INCQS) for kindly providing isolates. 


\section{CONFLICT OF INTEREST}

The authors declare that there is no conflict of interest.

\section{ABSTRACT IN PORTUGUESE}

\section{Níveis de glutationa e capacidade antioxidante total em células de Candida sp. expostas a estresse oxidativo causado por peróxido de hidrogênio}

Introdução: A capacidade de suportar o estresse oxidativo imposto por fagócitos parece ser crítica para que espécies de Candida causem candidíase invasiva. Métodos: Para melhor caracterizar a resposta ao estresse oxidativo (REO) de oito Candida sp. clinicamente relevantes, um componente vital do balanço redox intracelular, a glutationa, foi mensurada pelo método de reconversão DTNB-GSSG redutase e a capacidade antioxidante total (CAT) foi mensurada por um método modificado baseado na descoloração do ABTS*+. Ambos os métodos foram utilizados em extratos celulares das espécies de Candida tratadas ou não com peróxido de hidrogênio $(0,5 \mathrm{mM})$. Resultados: 0 estresse oxidativo induzido pelo peróxido de hidrogênio claramente reduziu os níveis intracelulares de glutationa. Esta diminuição foi mais intensa em C. albicans e os níveis de glutationa em células não tratadas foram também maiores nesta espécie. A capacidade antioxidante total demonstrou variação intraespecífica na capacidade antioxidante. Conclusões: Os níveis de glutationa não se correlacionaram com a capacidade antioxidante total mensurada, apesar desta ser a defesa antioxidante intracelular não-enzimática mais importante. Os resultados indicam que a medição isolada da CAT não fornece um quadro claro da habilidade de certa espécie de Candida responder ao estresse oxidativo.

Palavras-chaves: Candida sp. Glutationa. Capacidade antioxidante total.

\section{REFERENCES}

1. Furlaneto MC, Rota JF, Quesada RMB, Furlaneto-Maia L, Rodrigues R, Oda S, et al. Species distribution and in vitro fluconazole susceptibility of clinical Candida isolates in a Brazilian tertiary-care hospital over a 3-year period. Rev Soc Bras Med Trop 2011; 44:595-599.

2. Pfaller MA, Diekema DJ. Epidemiology of invasive candidiasis: a persistent public health problem. Clin Microbiol Rev 2007; 20:133-163.

3. Sobel JD. Changing trends in the epidemiology of Candida blood stream infections: A matter for concern? Critical Care Medicine 2010; 38:990-992.

4. Mochon AB, Ye J, Kayala MA, Wingard JR, Clancy CJ, Nguyen MH, et al. Serological Profiling of a Candida albicans Protein Microarray Reveals Permanent HostPathogen Interplay and Stage-Specific Responses during Candidemia. Plos Pathog 2010; 6:1-14.

5. Vazquez-Torres A, Balish E. Macrophages in resistance to candidiasis. Microbiol Mol Biol Rev 1997; 61:170-192.

6. Thompson HL, Wilton JMA. Interaction and intracellular killing of Candida albicans blastospores by human polymorphonuclear leukocytes, monocytes and monocytederived macrophages in aerobic and anaerobic conditions. Clin Exp Immunol 1992; 87:316-321

7. Stevenhagen A, Vanfurth R. Interferon-gamma activates the oxidative killing of Candida albicans by human granulocytes. Clin Exp Immunol 1993; 91:170-175.

8. Donini M, Zenaro E, Tamassia N, Dusi S. NADPH oxidase of human dendritic cells: Role in Candida albicans killing and regulation by interferons, dectin-1 and CD206. Eur J Immunol 2007; 37:1194-1203.

9. Aratani $\mathrm{Y}, \mathrm{Kura} F$, Watanabe $\mathrm{H}$, Akagawa $\mathrm{H}$, Takano $\mathrm{Y}$, Suzuki $\mathrm{K}$, et al. Critical role of myeloperoxidase and nicotinamide adenine dinucleotide phosphate-oxidase in high-burden systemic infection of mice with Candida albicans. J Infect Dis 2002; 185:1833-1837.
10. Lorenz MC, Bender JA, Fink GR. Transcriptional response of Candida albicans upon internalization by macrophages. Eukaryot Cell 2004; 3:1076-1087.

11. Costa CR, Souza LKH, Ataídes FS, Ferri PH, Costa MP, Fernandes OFL, et al. Molecular analysis and dimorphism of azole-susceptible and resistant Candida albicans isolates. Rev Soc Bras Med Trop 2011; 44:740-744.

12. Gonzalez-Parraga P, Marin FR, Arguelles JC, Hernandez JA. Correlation between the intracellular content of glutathione and the formation of germ-tubes induced by human serum in Candida albicans. Biochim Biophys Acta 2005; 1722:324-330.

13. Penninckx MJ. An overview on glutathione in Saccharomyces versus nonconventional yeasts. FEMS Yeast Res 2002; 2: 295-305.

14. Carmel-Harel $\mathrm{O}$, Storz $\mathrm{G}$. Roles of the glutathione- and thioredoxin-dependent reduction systems in the Escherichia coli and Saccharomyces cerevisiae responses to oxidative stress. Annu Rev Microbiol 2000; 54:439-461.

15. Grant $\mathrm{CM}$. Role of the glutathione/glutaredoxin and thioredoxin systems in yeast growth and response to stress conditions. Mol Microbiol 2001; 39:533-541.

16. Belozerskaya TA, Gessler NN. Reactive oxygen species and the strategy of antioxidant defense in fungi: A review. Appl Biochem Microbiol 2007; 43:506-515.

17. Young IS. Measurement of total antioxidant capacity. J Clin Pathol 2001; 54:339.

18. Erel O. A novel automated direct measurement method for total antioxidant capacity using a new generation, more stable ABTS radical cation. Clinical Biochemistry 2004; 37:277-285.

19. Erel O. A new automated colorimetric method for measuring total oxidant status. Clin Biochem 2005; 38:1103-1111.

20. Tosello ME, Biasoli MS, Luque AG, Magaro HM, Krapp AR. Oxidative stress response involving induction of protective enzymes in Candida dubliniensis. Med Mycol 2007; 45:535-540.

21. Cuéllar-Cruz M, Briones-Martin-Del-Campo M, Canas-Villamar I, MontalvoArredondo J, Riego-Ruiz L, Castaño I, et al. High resistance to oxidative stress in the fungal pathogen Candida glabrata is mediated by a single catalase, Cta1p, and is controlled by the transcription factors Yap1p, Skn7p, Msn2p, and Msn4p. Eukaryot Cell 2008; 7:814-825

22. Abegg MA, Alabarse PVG, Casanova A, Hoscheid J, Salomon TB, Hackenhaar FS, et al. Response to Oxidative Stress in Eight Pathogenic Yeast Species of the Genus Candida. Mycopathologia 2010; 170:11-20.

23. Rörig KCO, Colacite J, Abegg MA. Produção de fatores de virulência in vitro por espécies patogênicas do gênero Candida. Rev Soc Bras Med Trop 2009, 42:225-227.

24. Akerboom T, Sies H. Assay of glutathione, glutathione disulfide, and glutathione mixed disulfides in biological samples. Methods Enzymol 1981; 77:373-382.

25. Pacheco CC, Passos JF, Castro AR, Moradas-Ferreira P, Marco P. Role of respiration and glutathione in cadmium-induced oxidative stress in Escherichia coli K-12. Arch Microbiol 2008; 189:271-278.

26. Chauhan N, Inglis D, Roman E, Pla J, Li D, Calera JA, et al. Candida albicans response regulator gene SSK1 regulates a subset of genes whose functions are associated with cell wall biosynthesis and adaptation to oxidative stress. Eukaryot Cell 2003; 2:1018-1024

27. d'Enfert C, Hube B. Candida: comparative and functional genomics. Norfolk, U.K: Caister Academic Press; 2007.

28. Rhee SG, Kang SW, Chang TS, Jeong W, Kim K. Peroxiredoxin, a novel family of peroxidases. IUBMB Life 2001; 52:35-41.

29. Ng CF, Schafer FQ, Buettner GR, Rodgers VGJ. The rate of cellular hydrogen peroxide removal shows dependency on GSH: Mathematical insight into in vivo $\mathrm{H}_{2} \mathrm{O}_{2}$ and GPx concentrations. Free Radic Res 2007; 41:1201-1211.

30. Fekete A, Pocsi I, Emri T, Gyetvai A, Gazdag Z, Pesti M, et al. Physiological and morphological characterization of tert-butylhydroperoxide tolerant Candida albicans mutants. J Basic Microbiol 2008; 48:480-487.

31. Lemar KM, Aon MA, Cortassa S, O'Rourke B, Muller CT, Lloyd D. Diallyl disulphide depletes glutathione in Candida albicans: oxidative stress-mediated cell death studied by two-photon microscopy. Yeast 2007; 24:695-706.

32. Thomas D, Klein K, Manavathu E, Dimmock JR, Mutus B. Glutathione levels during thermal induction of the yeast-to-mycelial transition in Candida albicans. FEMS Microbiol Lett 1991; 77:331-334. 
33. Michan C, Pueyo C. Growth phase-dependent variations in transcript profiles for thioredoxin- and glutathione-dependent redox systems followed by budding and hyphal Candida albicans cultures. FEMS Yeast Res 2009; 9:1078-1090.

34. Schroter C, Hipler UC, Wilmer A, Kunkel W, Wollina U. Generation of reactive oxygen species by Candida albicans in relation to morphogenesis. Arch Dermatol Res 2000; 292:260-264.

35. Madeo F, Frohlich E, Ligr M, Grey M, Sigrist SJ, Wolf DH, et al. Oxygen stress: A regulator of apoptosis in yeast. J Cell Biol 1999; 145:757-67.

36. Fekete A, Emri T, Gyetvai A, Gazdag Z, Pesti M, Varga Z, et al. Development of oxidative stress tolerance resulted in reduced ability to undergo morphologic transitions and decreased pathogenicity in a t-butylhydroperoxide-tolerant mutant of Candida albicans. FEMS Yeast Res 2007; 7:834-847.

37. Lee YY, Kim SJ, Park EH, Lim CJ. Glutathione content and the activities of glutathionesynthesizing enzymes in fission yeast are modulated by oxidative stress. J Microbiol 2003; 41:248-251.

38. Manfredini V, Roehrs R, Peralba MCR, Henriques JA, Saffi J, Ramos AL, et al. Glutathione peroxidase induction protects Saccharomyces cerevisiae sod1 Delta sod2 Delta double mutants against oxidative damage. Braz J Med Biol Res 2004; 37:159-165.

39. Gonzalez-Parraga P, Sanchez-Fresneda R, Martinez-Esparza M, Arguelles JC. Stress responses in yeasts: what rules apply? Arch Microbiol 2008; 189:293-296

40. Dhindsa RS. Glutathione status and protein-synthesis during drought and subsequent rehydration in Tortula ruralis. Plant Physiol 1987; 83:816-819.

41. Schuppekoistinen I, Gerdes R, Moldeus P, Cotgreave IA. Studies on the reversibility of protein S-thiolation in human endothelial-cells. Arch Biochem Biophys 1994; 315:226-234.

42. Izawa S, Inoue Y, Kimura A. Oxidative stress-response in yeast - effect of glutathione on adaptation to hydrogen-peroxide stress in Saccharomyces cerevisiae. FEBS Lett 1995; 368:73-76.

43. Kobayashi $S$, Miyabe $S$, Izawa $S$, Inoue $Y$, Kimura A. Correlation of the OSR/ZRCI gene product and the intracellular glutathione levels in Saccharomyces cerevisiae. Biotechnol Appl Biochem 1996; 23:3-6.

44. Grant CM, Perrone G, Dawes IW. Glutathione and catalase provide overlapping defenses for protection against hydrogen peroxide in the yeast Saccharomyces cerevisiae. Biochem Biophys Res Commun 1998; 253:893-898.

45. Apak R, Güçlü K, Demirata B, Özyürek M, Çelik SE, Bektapoolu B, et al. Comparative evaluation of various total antioxidant capacity assays applied to phenolic compounds with the CUPRAC Assay. Molecules 2007; 12:1496-1547.

46. Re R, Pellegrini N, Proteggente A, Pannala A, Yang M. Antioxidant activity applying an improved ABTS radical cation decolorization assay. Free Radical Biol Med 1999; 26:1231-1237.

47. Sampaio P, Nogueira E, Loureiro AS, Delgado-Silva Y, Correia A, Pais C. Increased number of glutamine repeats in the C-terminal of Candida albicans RIm1p enhances the resistance to stress agents. Antonie Van Leeuwenhoek 2009; 96:395-404.

48. Lapshina EA, Jaruga E, Bilinski T, Bartosz $G$. What determines the antioxidant potential of yeast cells? Biochem Mol Biol Int 1995; 37:903-908.

49. Balcerczyk A, Grzelak A, Janaszewska A, Jakubowski W, Kozio S, Marszalek M, et al. Thiol as major determinants of the total antioxidant capacity. BioFactors 2003; 17:75-82.
50. Dubuisson M, VanderStricht D, Clippe A, Etienne F, Nauser T, Kissner R, et al. Human peroxiredoxin 5 is a peroxynitrite reductase. FEBS Letters 2004; 571:161-165.

51. Ogusucu R, Rettori D, Munhoz DC, Netto LES, Augusto O. Reactions of yeast thioredoxin peroxidases I and II with hydrogen peroxide and peroxynitrite: Rate constants by competitive kinetics. Free Radical Biol Med 2007; 42:326-334.

52. Ghaemmaghami S, Huh WK, Bower K, Howson RW, Belle A, Dephoure N, et al. Global analysis of protein expression in yeast. Nature 2003, 425:737-741.

53. Tachibana T, Okasaki S, Murayama A, Naganuma A, Nomoto A, Kuge S. A major peroxiredoxin-induced activation of Yap1 transcription factor is mediated by reduction-sensitive disulfide bonds and reveals a low level of transcriptional activation. J Biol Chem 2009, 284:4464-4472.

54. Iraqui I, Kienda G, Soeur J, Faye G, Baldacci G, Kolodner RD, et al. Peroxiredoxin Tsa1 is the key peroxidase suppressing genome instability and protecting against cell death in Saccharomyces cerevisiae. PLoS Genetics 2009, 5:e1000524.

55. Tang HMV, Siu KL, Wong CM, Jin DY. Loss of yeast peroxiredoxin Tsa1p induces genome instability through activation of the DNA damage checkpoint and elevation of dNTP levels. PLoS Genetics 2009, 5:e1000697.

56. Demasi APD, Pereira GAG, Netto LES. Yeast oxidative stress response influences of cytosolic thioredoxin peroxidase I ando f the mitochondrial functional state. FEBS Journal 2006, 273:805-816.

57. Park SG, Cha MK, Jeong W, Kim IH. Distinct physiological functions of thiol peroxidase isoenzymes in Saccharomyces cerevisiae. J Biol Chem 2000; 275:5723-5732.

58. Faria VG. Ahp1 and Tsa1 of Saccharomyces cerevisiae: genetic regulation, biochemical characterization, structure and function of the two most abundant yeast peroxiredoxins. [Doctoral Thesis]. [São Paulo]: Instituto de Biociências. Universidade de São Paulo; 2007. 160 p.

59. Jones T, Federspiel NA, Chibana H, Dungan J, Kalman S, Magee BB, et al. The diploid genome sequence of Candida albicans. Proc Natl Acad Sci USA 2004; 101:7329-34.

60. Urban C, Xiong X, Sohn K, Schröppel K, Brunner H, Rupp S. The moonlighting protein Tsa1 $\mathrm{p}$ is implicated in oxidative stress response and in cell wall biogenesis in Candida albicans. Mol Microbiol 2005; 57:1318-1341.

61. Shin DH, Jung S, Park SJ, Kim YJ, Ahn JM, Kim W, et al. Characterization of thiolspecific antioxidant 1 (TSA1) of Candida albicans. Yeast 2005; 22:907-918.

62. Chauhan N, Inglis D, Roman E, Pla J, Li D, Calera JA, et al. Candida albicans response regulator gene SSK1 regulates a subset of genes whose functions are associated with cell wall biosynthesis and adaptation to oxidative stress. Eukaryot Cell 2003; 2:1018-1024

63. Missall TA, Lodge JK, McEwen JE. Mechanisms of resistance to oxidative and nitrosative stress: Implications for fungal survival in mammalian hosts. Eukaryot Cell 2004; 3:835-846.

64. Balish E, Warner TF, Nicholas PJ, Paulling EE, Westwater C, Schofield DA. Susceptibility of germfree phagocyte oxidase- and nitric oxide svnthase 2-deficient mice defective in the production of reactive metabolites of both oxygen and nitrogen, to mucosal and systemic candidiasis of endogenous origin. Infect Immun 2005; 73:1313-1320.

65. Wellington M, Dolan K, Krysan DJ. Live Candida albicans Suppresses Production of Reactive Oxygen Species in Phagocytes. Infect Immun 2009; 77:405-413. 